\title{
JAMINAN KEPASTIAN HUKUM YANG TERKANDUNG DALAM SERTIPIKAT HAK ATAS TANAH
}

\author{
Rahmat Ramadhani \\ Fakultas Hukum Universitas Muhammadiyah Sumatera Utara \\ E-mail: dhanilla1980@gmail.com
}

\begin{abstract}
The product of the land registration process is a certificate of title granted to the right holder. The certificate according to Government Regulation No. 24 of 1997 is in the form of one sheet of documents containing information about the juridical data and physical data required on a parcel of registered land. Although the certificate of land rights is referred to as the strongest evidence but in reality the certificate of land rights has not fully guaranteed legal certainty. This is because the law still opens loopholes for other legal subjects to question it both personally and in groups within the judiciary. In order to ensure legal certainty of a right to land for the right holder, the certificate of land rights must be tested in three aspects: relating to; Legal Certainty of Object, Legal Certainty of Status of Rights and Legal Certainty on Subject.
\end{abstract}

\section{Kata Kunci: Hak Atas Tanah, Jaminan Kepastian Hukum, Sertipikat}

\section{A. Latar Belakang}

Dalam rangka menuju terciptanya kepastian hukum terhadap hak-hak atas tanah maka diperlukan pondasi hukum yang kuat. Pondasi hukum terkait dengan masalah keagrariaan di Indonesia secara umum diatur dalam Undang-Undang Nomor 5 Tahun 1960 tentang Peraturan Dasar Pokok-Pokok Agraria yang lebih dikenal dengan sebutan Undang-undang Pokok Agraria (UUPA). Istilah agraria menurut UUPA memiliki pengertian tidak hanya sebatas tanah, melainkan juga meliputi bumi, air dan kekayaan alam yang terkandung di dalamnya. Bahkan menurut Boedi Harsono (2007: 34-35), ruang angkasa juga termasuk di dalamnya, dimana di atas bumi dan air mengandung tenaga dan unsur-unsur yang dapat digunakan untuk usaha-usaha memelihara dan mengembangkan kesuburuan bumi, air serta kekayaan alam dan hal-hal lain yang berhubungan dengan hal tersebut.

Lebih lanjut, produk (output) dari suatu proses pendaftaran tanah adalah sertipikat tanda bukti hak yang diberikan kepada pemegang haknya. Sertipikat 
menurut Peraturan Pemerintah Nomor 24 Tahun 1997 tentang Pendaftaran Tanah (selanjutnya disingkat PP No. 24 Tahun 1997) adalah berupa satu lembar dokumen yang memuat informasi tentang data yuridis dan data fisik yang diperlukan terhadap suatu bidang tanah yang didaftarkan haknya.

Sertipikat juga sering diartikan sebagai gabungan antara Surat Ukur (lembaran yang memuat data obyek bidang tanah) dengan buku tanah (lembaran yang memuat data subyek yang menguasai bidang tanah serta data yang menerangkan aspek yuridis bidang tanahnya) yang telah di tandatangani serta di cap oleh pejabat yang berwenang (Badan Pertanahan Nasional) yang kemudian dijilid dan dijahit serta diberi segel lambang burung Garuda Pancasila.

Sertipikat hak atas tanah merupakan benang merah yang menghubungkan antara kepastian hukum, bidang tanah dan pemegang hak. Lebih jauh, meskipun Pasal 19 ayat (2) huruf (c) PP No. 24 Tahun 1997 menegaskan bahwa: "Pemberian surat-surat tanda bukti hak (sertipikat) yang berlaku sebagai alat bukti yang kuat", tetapi hal yang ditegaskan dalam pasal tersebut belum menjamin sepenuhnya kepastian dan perlindungan hukum bagi pemegang hak atas tanah., karena sistem pendaftaran tanah Indonesia yang menganut sistem stelsel negatif bertendensi positif, artinya segala apa yang tercantum dalam buku tanah dan Sertipikat hak atas tanah berlaku sebagai tanda bukti yang kuat sampai dapat dibuktikan suatu keadaan sebaliknya yang tidak benar (Adrian Sutedi, 2012: vi). Di sisi lain, pembuktian ketidakbenaran data sebagaimana dimaksud dalam sistem pendaftaran stelsel negarif bertendensi positif memiliki batasan waktu bagi pihak lain yang berkeberatan atas suatu hak yang dipegang oleh pemegang hak atas tanah.

Batasan waktu tersebut dijabarkan dalam Pasal 32 ayat (2) PP No. 24 Tahun 1997, yang menentukan bahwa:

Dalam hal atas suatu bidang tanah sudah diterbitkan sertipikat secara sah atas nama orang atau badan hukum yang memperoleh tanah tersebut dengan itikad baik dan secara nyata menguasainya, maka pihak lain yang merasa mempunyai hak atas tanah itu tidak dapat lagi menuntut pelaksanaan hak tersebut apabila dalam waktu 5 (lima) tahun sejak diterbitkannya sertipikat itu tidak mengajukan keberatan secara tertulis kepada pemegang sertipikat dan Kepala Kantor Pertanahan yang 
bersangkutan ataupun tidak mengajukan gugatan ke Pengadilan mengenai penguasaan tanah atau penerbitan sertipikat tersebut.

Kemungkinan munculnya masalah pertanahan bukan hanya terhadap bidang-bidang tanah yang belum terdaftar saja, bahkan yang sudah terdaftar (bersertipikat) pun masih menyimpan masalah apalagi yang belum atau tidak didaftar (Muhammad Yamin Lubis dan Abdul Rahim Lubis, 2012: 7). Artinya, sertipikat hak atas bidang tanah yang sudah terdaftar juga memungkinkan masih menyimpan segudang masalah baik menyangkut pihak lain (subyek hak lain) maupun menyangkut subyek pemegang hak sebagaimana yang tercantum dalam sertipikat hak atas tanah (dirinya sendiri).

Masalah ketidakpastian hukum sertipikat hak atas tanah menyangkut subyek hak lain (pihak lain) dapat berupa klaim pihak lain menyangkut penguasaan bidang tanah yang tumpang tindih, sertipikat ganda, dan sengketasengketa lain yang mengandung aspek-aspek sosial praktis dan bersifat strategis (Rusmadi Murod, 1991: 23), sedangkan persoalan yang menyangkut antara diri pemegang hak dengan sertipikat hak atas tanah yang dipegangnya (dirinya sendiri), yaitu kerap ditemukannya perbedaan indentitas subyek pemegang hak yang tidak sesuai antara yang tertulis di buku tanah atau sertipikat hak atas tanah dengan identitas bukti diri yang asli (KTP untuk orang perorangan, Akta Pendirian untuk badan hukum, dan lain sebaginya).

Berdasarkan uraian tersebut di atas, maka jaminan kepastian hukum terhadap sertipikat hak atas tanah menjadi penting untuk dibahas. Pembahasan dimaksud tentunya wajib dilakukan secara komprehensif guna mengetahui bagian-bagian yang dijamin kepastian hukumnya oleh kegiatan pendaftaran tanah di Indonesia yang terbungkus rapi dalam sebuah sertipikat hak atas tanah.

\section{B. Metode Penelitian}

Sesuai dengan permasalahan yang diteliti, penelitian ini merupakan penelitian hukum (legal research). Istanto (2007: 29) mengatakan penelitian hukum adalah penelitian yang diterapkan atau diberlakukan khusus pada ilmu hukum. Marzuki (2005: 35) mengatakan penelitian hukum adalah suatu proses 
untuk menemukan aturan hukum, prinsip-prinsip hukum, maupun doktrin-doktrin hukum guna menjawab isu-isu hukum yang dihadapi.

Berangkat dari pemahaman tersebut, maka penelitian ini termasuk ke dalam penelitian hukum guna mencari jawaban persoalan jaminan kepastian hukum yang terkandung di dalam sertipikat hak atas tanah, penelitian ini termasuk ke dalam penelitian hukum dengan pendekatan doktrinal yang condong bersifat kualitatif berdasarkan data sekunder (Supranto, 2003: 2).

Jenis penelitian yang digunakan dalam penulisan ini adalah penelitian pustaka (library research). Library research berarti penelitian yang menggunakan dokumen tertulis sebagai data, dan sumber data yang digunakan dalam penelitian ini mencakup bahan hukum primer dan bahan hukum sekunder. Bahan hukum primer adalah bahan hukum yang mengikat atau yang membuat orang taat hukum, meliputi produk hukum yang menjadi bahan kajian dan produk hukum sebagai alat kritiknya. Bahan hukum sekunder meliputi penjelasan bahan hukum primer berupa doktrin para ahli yang ditemukan dalam buku, jurnal, dan website. Sementara itu, Cohen sebagaimana dikutip Marzuki (2005: 93). mengatakan dalam penelitian hukum (legal research) terdapat beberapa pendekatan yang digunakan, yaitu: statute approach, conceptual approach, analitycal approach, comparative approach, hystorical approach, philosophical approach, dan case approach.

Merujuk pada pendekatan-pendekatan tersebut, penulis menggunakan pendekatan perundang-undangan (statute approach), pendekatan konseptual (conceptual approach), pendekatan sejarah (hystorical approach), dan pendekatan filosofis (philosophical approach). Pendekatan perundang-undangan digunakan untuk melihat permasalahan jaminan kepastian hukum yang terkandung di dalam sertipikat hak atas tanah yang diatur dalam Undang Undang Dasar Negara Republik Indonesia (UUD) 1945, UUPA dan PP No. 24 Tahun 1997.

Pendekatan konseptual digunakan untuk melihat konsepsi jaminan kepastian hukum yang terkandung di dalam sertipikat hak atas tanah dan negara hukum, sedangkan pendekatan sejarah dipergunakan dengan melihat sejarah pembentukan undang-undang keagrarian di Indonesia. Pendekatan filosofis 
digunakan untuk melihat makna esensial jaminan kepastian hukum agar sejalan dengan filosofi jaminan keamanan yang diberikan oleh negara. Melalui pendekatan-pendekatan tersebut, maka perkembangan pemaknaan jaminan kepastian hukum yang terkandung di dalam sertipikat hak atas tanah dianalisis secara deskriptif kualitatif agar dapat sampai pada kesimpulan akhir yang akan menjawab semua pokok permasalahan dalam penelitian

\section{Hasil Penelitian dan Analis}

\section{Konsepsi kepastian hukum hak atas tanah}

Untuk membidik denotasi kata kepastian hukum maka sudah barang tentu harus terlebih dahulu mengetahui arti kata dari kepastian hukum itu sendiri. Kepastian hukum terdiri dari dua suku kata yaitu; kepastian dan hukum. Kepastian adalah suatu perihal (keadaan) yang pasti, ketentuan atau ketetapan (Cst Kansil, Christine St. Kansil, Etc., 2009: 385), sedangkan hukum menurut Sudikno Mertokusumo dalam H. Salim Hs. (2010: 24) adalah: "kumpulan peraturanperaturan atau kaidah-kaidah dalam suatu kehidupan bersama, keseluruhan peraturan tentang tingkah laku yang berlaku dalam suatu kehidupan bersama, yang dapat dipaksakan pelaksanaanya dengan suatu sanksi”.

Melihat dua pengertian di atas maka kepastian hukum dapat diartikan sebagai sebuah keadaan yang pasti dan sesuai dengan ketetepan serta ketentuan dari tujuan dibentuknya suatu hukum. Kepastian hukum erat kaitannya dengan rasa aman dan nyaman, sebab hakikat dari kepastian hukum adalah menimbulkan kepastian terhadap segala sesuatu yang menyangkut keraguan, ketidakpastian dan rasa ketakutan yang bersifat manusiawi. Lebih jauh lagi, kajian tentang kepastian hukum erat kaitanya dengan kajian suatu keabsahan. Kaadaan yang pasti dinilai sebuah keadaan yang sah menurut peraturan peundang-undangan baik secara formil maupun materil.

Konsepsi kepastian hukum menurut Gustav Radbruch, dapat dilihat dari dua aspek (Surabaya Pagi, http://www.surabayapagi.com), yaitu:

a. Kepastian hukum oleh karena hukum; dimana pandangan ini memberi batasan bahwa hukum yang berhasil menjamin banyak kepastian hukum dalam 
masyarakat adalah hukum yang berguna, oleh karenanya hokum bertugas sebagai jaminan keadilan hukum serta hukum harus tetap berguna.

b. Kepastian hukum dalam atau dari hukum; yaitu kepastian hukum oleh karena hukum, dimana hal ini tercapai, apabila hukum tersebut sebanyak-banyaknya undang-undang. Dalam undang-undang tersebut tidak terdapat ketentuanketentuan yang bertentangan (undang-undang berdasarkan suatu sistem yang logis dan praktis). Undang-undang dibuat berdasarkan rechtswerkelijkheid (keadaan hukum yang sungguh-sungguh) dan dalam undang-undang tersebut tidak terdapat istilah-istilah yang dapat ditafsirkan secara berlain-lainan.

Pada kenyataanya apabila kepastian hukum dikaitkan dengan keadilan hukum, maka akan kerap kali tidak sejalan satu sama lain. Adapun hal ini dikarenakan di satu sisi tidak jarang kepastian hukum mengabaikan prinsipprinsip keadilan hukum, sebaliknya tidak jarang pula keadilan hukum mengabaikan prinsip-prinsip kepastian hukum. Apabila dalam praktiknya terjadi pertentangan antara kepastian hukum dan keadilan hukum, maka keadilan hukum yang harus diutamakan. Alasannya adalah, bahwa keadilan hukum pada umumnya lahir dari hati nurani pemberi keadilan, sedangkan kepastian hukum lahir dari suatu yang konkrit.

Berkaitan dengan teori kepastian hukum sebagaimana dikemukan di atas, Muchtar Wahid (2008: 115), merangkai kerangka pemikiran mengenai kepastian hukum hak atas tanah ditentukan oleh berfungsinya 3 (tiga) hal, yaitu:

a. Substansi Hukum, terdiri dari tujuan, sistem dan tata laksana pendaftaran tanah;

b. Struktur Hukum, terdiri dari aparat pertanahan dan lembaga penguji kepastian hukum, bahkan juga lembaga pemerintah terkait;

c. Kultur hukum, terdiri dari kesadaran hukum masyarakat dan realitas sosial. Untuk memaparkan posisi masing-masing faktor yang menentukan kepastian hukum hak atas tanah, lebih lanjut dapat digambarkan secara garis besar dalam skema teoritis berikut: 


\section{Gambar 1 \\ Skema Teoritis Pengaruh Faktor-faktor terhadap Kepastian Hukum Hak Atas Tanah}

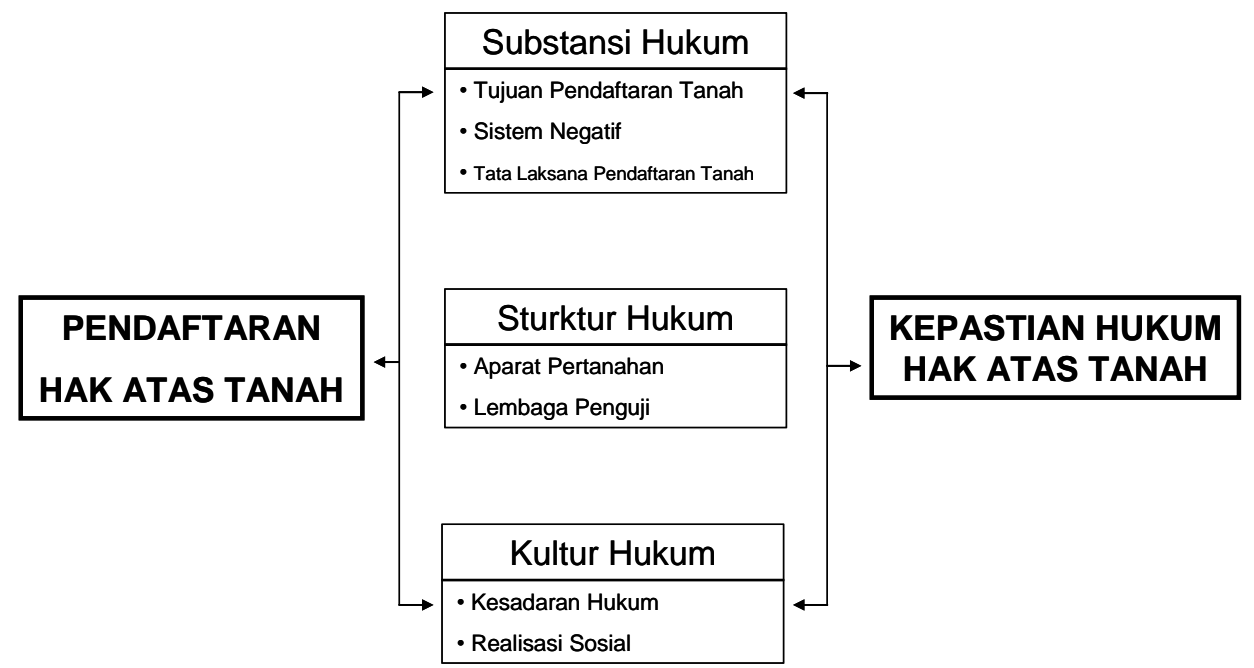

Dalam kajian secara sosiologis kepastian hukum hak atas tanah ada dua bagian yang perlu ditelaah, yakni; bagian pertama meyangkut proses penerbitan sertipikat hak atas tanah oleh institusi BPN RI dan bagian kedua adalah menyangkut lembaga peradilan yang berfungsi sebagai lembaga penyaring yang oleh para pakar disebut dengan kutub pengaman (Muchtar Wahid, 2008: 115). Lebih jauh lagi, proses penerbitan sertipikat hak atas tanah menurut Muchtar Wahid merupakan hasil dari berfungsinya substansi hukum, sturktur hukum dan kultur hukum. Substansi hukum dalam hal ini meliputi peraturan perundangundangan yang menjadi dasar pelaksanaan kebijakan, sistem dan tujuan pendaftaran tanah dan tata laksananya. Sedangkan struktur hukum mencakup keadaan institusi dan aparat pelaksana kegiatan pendaftaran tanah (BPN RI).

Sertipikat hak atas tanah yang diterbitkan pada kenyataannya masih mengandung kelemahan menyangkut kepastian hukum atas hak nya karena masih dapat dipermasalahkan oleh subyek hukum lain baik secara personal maupun berkelompok (masyarakat) di lembaga peradilan. Oleh karenanya untuk sertipikat hak atas tanah yang demikian, baru dapat dikatakan memiliki kekuatan hukum pasti setelah memperoleh putusan hakim.

Adapun kultur hukum dalam masyarakat yang meliputi kesadaran hukum masyarakat dan realitas sosial berpengaruh dalam proses penerbitan sertipikat hak 
atas tanah dan proses pengujian kepastian hukum di lembaga peradilan. Dalam proses penerbitan sertipikat hak atas tanah, kultur hukum masyarakat berperan dalam memberikan keterangan tentang kebenaran data fisik dan data yuridis atas tanah. Kultur hukum masyarakat juga berperan dalam proses peradilan yang merupakan lembaga penguji atas kebenaran keterangan masyarakat tersebut yang diberikan pada awal proses penerbitan sertipikat hak atas tanah.

Ketiga faktor sebagaimana dikemukakan oleh Muchtar wahid di atas, yakni: subtansi hukum, struktur hukum dan kultur hukum, secara teoritis akan memainkan peranannya masing-masing dalam proses Penetapan Hak, Penerbitan Buku Tanah dan Sertipikat Hak Atas Tanah, yang merupakan produk hukum pendaftaran tanah.

Kadar kepastian hukum sertipikat sebagai tanda bukti hak yang kuat, tidak hanya ditentukan oleh terpenuhinya aturan hukum secara formil, tetapi lebih penting adalah sejauhmana penerapan aturan-aturan secara benar sehingga substansi hukum terpenuhi (Muchtar Wahid, 2008: 117). Oleh karena itu alur proses permohonan dan perekaman data fisik dan yuridis, serta subyek hak harus dilaksanakan secara seksama sesuai dengan peraturan perundang-undangan dan petunjuk pelaksanaan pendaftaran tanah yang berlaku.

Merujuk pada PP No. 24 Tahun 1997, Muchtar Wahid (2008: 126-127) menekankan dua hal pokok tentang tujuan atau hakikat pendaftaran tanah yang subtansinya menjamin kepastian hukum, yakni:

a. Kelompok teknis; menekankan pada segi-segi teknis operasional, mengenai faktor kepastian obyek yang meliputi luas, letak dan batas-batas tanah.

b. Kelompok yuridis; terletak pada segi-segi yang bersifat legalitas tanah, mengenai faktor kepastian status hukum bidang tanah yang terdaftar, asal-usul pemilikan dan cara perolehan tanah, serta faktor kepastian subyek hak yang meliputi identitas, domisili kewarganegaraan, dan pihak lain serta bebanbeban yang membebaninya.

Ada dua informasi yang dituangkan dalam sertipikat: pertama, data fisik yang menurut Pasal 1 angka 6 PP No. 24 Tahun 1997 adalah keterangan mengenai letak, batas dan luas bidang tanah dan satuan rumah susun yang didaftar serta 
keterangan mengenai bangunan atau bagian bangunan di atasnya, dan kedua, data yuridis, yang menurut Pasal 1 angka 7 PP No. 24 Tahun 1997 adalah keterangan mengenai status hukum bidang tanah dan satuan rumah susun yang didaftar, tentang pemegang haknya dan pihak-pihak lain, serta beban-beban lain yang membebaninya.

Kedua informasi data di atas yang dituangkan dalam sertipikat adalah merupakan cuplikan atau salinan dari buku tanah. Buku tanah menurut Pasal 1 angka 19 PP No. 24 Tahun 1997 adalah dokumen dalam bentuk daftar yang memuat data fisik dan data yuridis suatu objek pendaftaran tanah yang sudah ada haknya, sehingga dengan diterbitkannya sertipikat hak atas tanah dalam kegiatan pendaftaran tanah bertujuan agar pemegang hak dengan mudah dapat membuktikan bahwa dirinya sebagai pemegang hak (Urip Santoso, 2013: 261).

\section{Jaminan kepastian hukum dalam sertipikat hak atas tanah.}

Pendaftaran tanah bertujuan untuk menjamin kepastian hukum hak atas tanah. Penegasan akan hal tersebut dapat dilihat pada Pasal 19 ayat (1) UUPA jo. Pasal 3 huruf (a) PP No. 24 Tahun 1997 yang pada intinya tujuan dari pendaftaran tanah adalah untuk memberikan kepastian hukum dan perlindungan hukum kepada pemegang hak atas suatu bidang tanah. Dalam rangka mencapai tujuan pedaftaran tanah tersebut di atas, maka akhir dari proses pendaftaran tanah menghasilkan sertipikat hak atas tanah sebagai produk pendaftaran tanah sebagaimana ditegaskan dalam Pasal 19 ayat (2) huruf c UUPA jo. Pasal 4 ayat (1) PP No. 24 Tahun 1997.

Muchtar Wahid (2008: 127), menjabarkan tentang kontruksi hukum yang ingin dibangun oleh PP No. 24 Tahun 1997 yaitu untuk menjamin adanya kepastian hukum dalam penerbitan suatu sertipikat hak atas tanah yaitu meliputi; kepastian obyek, kepastian hak dan kepastian subyek, yang dapat dijabarkan sebagai berikut:

a. Kepastian hukum obyek hak

Penetapan letak tepat bidang tanah merupakan salah satu yang sangat menentukan nilai kepastian hukum hak atas tanah yang terdaftar. Kepastian obyek hak ini meliputi letak dan batas-batas bidang tanah yang dilekati suatu 
hak di atasnya. Terkait dengan kepentingan tersebut tersedianya Peta Dasar Pendaftaran Tanah sangat diperlukan, terutama untuk memastikan letak tepat sebidang tanah yang sudah dilekati suatu hak, serta keberadaan bidang-bidang tanah lainnya, baik yang sudah terdaftar maupun yang belum terdaftar.

Hal ini dilakukan dengan tujuan agar dapat dilakukannya rekonstruksi ulang untuk menghidari kemungkinan munculnya sengketa di kemudian hari, baik yang berkaitan dengan letak, luas maupun batas. Oleh karenanya untuk memenuhi prinsip kehati-hatian, maka pengukuran dan penetapan batas bidang tanah harus disertai dengan persetujuan oleh tetangga atau sepadan batas bidang tanah tersebut (contradictoire dilimitatie).

Kendala yang kerap dihadapi dalam pelaksanaan pengukuran bidang tanah pada umumnya adalah sulitnya menghadirkan para pemilik tanah yang bersebalahan atau berbatasan dengan obyek tanah yang akan dimohonkan haknya, terutama dalam kegiatan pendaftaran tanah pertama kali secara sporadik ataupun secara missal (misalkan dalam kegiatan PRONA), dimana pemohon dan pemilik tanah yang berbatasan sulit untuk dihadirkan pada saat dilakukannya pengukuran bidang dan hanya memasrahkan segala urusan kepada perangkat desa/kelurahan sebagai panitia pelaksana di tingkat desa/ kelurahan.

Selain itu, terkadang pemohon tidak mengetahui secara pasti batas bidang tanah yang benar, sehingga pelaksanaan penandatangan veldwerk atau gambar ukur (GU) bidang tanah sulit mendapatkan data yang pasti dan sering kali dilakukan dengan tidak sebagaimana mestinya. Dan hal ini sudah barang tentu akan berpengaruh kepada berkurangnya substansi kepastian hukum akan obyek hak dimaksud sehingga menimbulkan ketidakpastian letak dan batasbatas bidang tanah serta berpotensi akan munculnya sengketa batas.

Oleh sebab itu, pemasangan tanda batas merupakan suatu sarat mutlak sebelum dilakukannya pengukuran bidang tanah. Hal tersebut merupakan perintah undang-undang sebagaimana disebutkan dalam Pasal 17 PP No. 24 Tahun 1997, yaitu: 
Ayat (1): Untuk memperoleh data fisik yang diperlukan bagi pendaftaran tanah, bidang-bidang tanah yang akan dipetakan diukur, setelah ditetapkan letaknya, batas-batasnya dan menurut keperluannya ditempatkan tanda-tanda batas di setiap sudut bidang tanah yang bersangkutan.

Ayat (2): Dalam penetapan batas bidang tanah pada pendaftaran tanah secara sistematik dan pendaftaran tanah secara sporadik diupayakan penataan batas berdasarkan kesepakatan para pihak yang berkepentingan.

Ayat (3): Penempatan tanda-tanda batas termasuk pemeliharaannya, wajib dilakukan oleh pemegang hak atas tanah yang bersangkutan.

Ayat (4): Bentuk, ukuran, dan teknis penempatan tanda batas di-tetapkan oleh Menteri.

Petunjuk lebih lanjut mengenai bentuk patok tanda batas sebagaimana dimaksud di atas diatur lebih lanjut pada Pasal 22 PMNA/Ka.BPN No. 3 Tahun 1997, sedangkan untuk batas sudut bidang-bidang tanah yang sudah jelas letaknya karena ditandai oleh benda-benda yang terpasang secara tetap seperti pagar beton, pagar tembok atau tugu/patok penguat pagar kawat, tidak harus dipasang tanda batas (vide) Pasal 21 ayat (2) PMNA/Ka.BPN No. 3 Tahun 1997).

Pemasangan patok tanda batas serta persetujuan sepadan batas tanah sebelah menyebelah memiliki peranan yang sangat penting dalam proses pengukuran bidang tanah untuk menghasilkan peta bidang dan peta dasar pendaftaran tanah dengan kualitas substansi kepastian hukum yang baik. Kebutuhan peta pendaftaran tanah yang lengkap sangat penting karena peta tersebut memuat secara jelas titik-titik dasar teknik dan unsur-unsur geografis yang meliputi letak, bentuk dan batas-batas pemilikan setiap bidang tanah dalam suatu wilayah sehingga dapat menghindari tumpang tindih suatu lokasi bidang tanah (Muchtar Wahid, 2008: 115).

Sesuai dengan ketentuan yang berlaku, semula pengukuran kadasteral untuk memperoleh peta pendaftaran tanah dilakukan desa demi desa. Hal 
tersebut dilakukan dengan maksud agar setiap bidang tanah memperoleh kepastian letak tepat, tetapi karena berbagai kendala pelaksanaannya belum dapat diselenggarakan sebagaimana yang diharapakan. Selama berlakunya PP No. 10 Tahun 1961, pengukuran desa demi desa dilaksanakan dengan hasil masih sangat terbatas, dan setelah berlakunya PP NO. 24 Tahun 1997, dengan berbagai keterbatasan maka untuk memperoleh peta dasar pendaftaran tanah dilakukan tidak lagi mengacu pada pengukuran desa demi desa, melainkan dalam kegiatan pendaftaran tanah secara sporadik (Muchtar Wahid, 2008: 129).

b. Kepastian hukum status tanah

Kajian terhadap status hukum suatu hak atas tanah penting dilakukan untuk menggali tentang jaminan kepastian hukum terhadap sertipikat hak atas tanah yang akan diterbitkan. Ada berbagai macam status hukum atas tanah yang masing-masing status tersebut mengandung hak dan kewajiban kepada pihak yang mempunyainya (Muchtar Wahid, 2008: 130).

Ragam status tanah sendiri seperti di antaranya; Tanah Hak Milik Adat, Tanah Swapraja dan Bekas Swapraja dan Tanah Negara. Terhadap tanah-tanah yang memiliki status demikian berdasarkan UUPA dapat diberikan haknya, tetapi untuk dapat memberikan jaminan kepastian hukum, maka pendaftaran tanah yang dilakukan terhadap status tanah tersebut secara materil harus sesuai dengan tata laksana pendaftaran tanah sebagaimana mestinya.

Selain status tanah tersebut di atas, masih terdapat beberapa status tanah yang lainnya yang mendapat catatan khusus dalam pendaftaran tanah khususnya pendaftaran tanah pertama kali dalam rangka penerbitan sertipikat. Catatan khusus dimaksud adalah merupakan tanah-tanah yang pemanfaatan dan penggunaanya tidak bertentangan Rencana Tata Ruang Wilayah Nasional maupun Daerah setempat yang diatur berdasarkan peraturan perundangundangan. Bahkan ada beberapa zona tanah yang tidak dapat dilekati suatu hak atau diberikan haknya kepada subyek hukum dan merupakan daerah terlarang untuk diterbitkan sertipikatnya. Seperti tanah-tanah yang termasuk di 
dalam kawasan lindung, contohnya tanah-tanah yang masuk ke dalam spadan sungai, jalan, laut dan lain sebagainya.

Dalam penerbitan sertipikat hak atas tanah harus disesuaikan dengan status tanah yang melekat sebelumnya, itu berarti jika sertipikat hak diterbitkan di atas tanah yang secara substansi status tanahnya merupakan tanah yang tidak boleh dilekati oleh suatu hak menurut hukum, maka hal demikian dari aspek hukum publik sertipikat dimaksud dikatakan sebagai sebuah keputusan tata usaha negara yang cacat materil. Hal itu berarti pula bahwa sertipikat dimaksud mengandung cacat hukum sehingga terhadap sertipikat dimaksud tidak akan menjamin adanya kepastian hukum.

c. Kepastian hukum subyek hak

Pembahasan seputar masalah pertanahan memang seakan tidak ada habisnya, hal tersebut sejalan dengan bertambahnya populasi manusia sebagai subjek hukum yang mendongkrak angka kebutuhan akan tanah dan pemanfaatannya, tetapi berbanding terbalik dengan jumlah ketersediaan tanah yang cenderung bersifat statis (Rahmat Ramadhani, 2012: 4).

Terwujudnya suatu jaminan kepastian hukum sertipikat hak atas tanah juga dipengaruhi oleh kepastian akan subyek hukum sebagai pemegang hak atas tanah (subjek hak), sebab dari kajian kepastian subyek hak ini setidaknya akan menjawab tentang siapa yang berhak. Menurut Muchtar Wahid (2008: 135) kepastian subyek adalah:

Kepastian mengenai siapa yang mempunyai, diperlukan untuk mengetahui dengan siapa yang berhubungan untuk dapat melakukan perbuatan hukum secara sah, mengenai ada atau tidaknya hak-hak dan kepentingan pihak ketiga, serta untuk mengetahui perlu atau tidaknya diadakan tindakan-tindakan untuk menjamin penguasaan dan penggunaan tanah yang bersangkutan secara efektif dan aman.

Tekait dengan hal tersebut, penelitian akan riwayat penguasaan tanah juga merupakan suatu kegiatan yang sangat penting strategis dan hasilnya merupakan faktor penentu kebenaran aspek yuridis dalam penerbitan sertipikat hak atas tanah. Penelitian terhadap riwayat penguasaan tanah ini setidaknya dituntut untuk dapat menemukan informasi tentang proses penguasaan dan peralihan-peralihannya termasuk pihak-pihak yang menguasai tanah sebelum 
tanah dikuasai pemohon. Dengan arti kata lain, kepastian subyek hak merupakan upaya untuk membuktikan kebenaran hak yang dimohonkan dilakukan dengan cara menelaah riwayat penguasaan/pemilikan tanah secara runtut dari awal sampai dengan dikuasai/dimiliki oleh si pemohon hak termasuk proses perolehan haknya (baik penguasaan langsung maupun peralihan atau pemindahan hak). Telaah akan hal tersebut ditujukan untuk menemukan adanya itikad baik atau sebaliknya dari pemohon dan hal ini sudah barang tentu juga berefek pada penentuan kadar kepastian hukum sertipikat hak atas tanah.

Kepastian subyek memiliki perananan penting dalam mendudukan dan menunjukan siapa yang berhak atau tidak dalam penguasaan, pemilikan dan pemanfaatan suatu bidang tanah. Sehingga untuk melihat secara detail tentang kepastian subyek hak ini, maka unsur-unsur yang penting untuk diteliti ada berkaitan dengan identitas subyek, domisili, pekerjaan, kewarganegaraan dan lain sebagainya.

Berdasarkan UUPA, ada 4 sebab lahirnya tanah hak yaitu; tanah hak yang lahir karena hukum adat, tanah hak yang lahir karena penetapan pemerintah, tanah hak yang lahir karena undang-undang dan tanah hak yang lahir karena pemberian (Urip Santoso, 2013: 54-58), sedangkan pihak yang dapat ditunjuk sebagai subjek hak untuk memiliki atau menguasi tanah hak, adalah (Urip Santoso, 2015: 218):

1) Perseorangan (Naturlijk Person): baik individu maupun sekelompok individu secara bersama-sama berkewarganegaraan Indonesia maupun berkewarganegaraan asing yang berkedudukan di Indonesia.

2) Badan hukum (Recht Person): meliputi Lembaga Negara, Kementerian, Lembaga Pemerintah Non-Kementrian, Badan Otorita, Pemerintah Provinsi, Pemerintah Kabupaten/Kota, Pemerintah Desa, Badan Usaha Milik Negara, Badan Usaha Milik Daerah, Badan Keagamaan, Badan Sosial, Badan Hukum Asing yang mempunyai Perwakilan di Indonesia, Perwakilan Negara Asing, Perwakilan Badan Internasional, Perseroan Terbatas, dan Yayasan. 
Tanah hak yang dipunyai atau dimiliki oleh subjek hak tentunya memiliki batasan-batasan kewenangan tertentu. Batasan kewenangan tersebut telah digariskan oleh UUPA sesuai dengan jenis hak yang diperoleh dan tertulis dalam Sertipikat Hak Atas tanah. Sesuai dengan title nya maka di dalam hak atas tanah selain memiliki kewenangan sebagai salah satu bentuk hak juga memiliki kewajiban-kewajiban dalam mempertahankan haknya tersebut terhadap suatu bidang tanah. Tidak sesuainya hak dan kewajiban inilah yang kemudian senantiasa memunculkan persoalan hukum tersendiri yang bertalian dengan tanah yang dikenal dengan istilah sengketa, konflik dan perkara pertanahan. Dengan demikian, semakin luaslah pengertian subyek hak, meskipun dikategorikan ke dalam dua klasifikasi, tetapi untuk yang berstatus badan hukum sebagai subyek pemberian hak jauh lebih luas penjabarannya dibandingkan dengan pengertian badan hukum sebagai subyek hukum, dan jika dikaitkan antara subyek hukum dengan subyek pemberian hak sebagaimana dijabarkan di atas, maka pada prisnsipnya adalah sama. Artinya, subyek hukum juga merupakan subyek hak.

Perbuatan hukum pendaftaran tanah maupun pendaftaran hak atas tanah adalah peristiwa penting karena menyangkut segi hak keperdataan seseorang bukan hanya sekedar kegiatan administratif (Samun Ismaya, 2013: 81). Hak keperdataan seseorang merupakan hak asasi manusia yang harus dijunjung tinggi dan dihormati oleh sesama manusia lainnya dalam rangka terwujudnya kedamaian dalam hubungan kemasyarakatan (Bachtiar Effendi, 1993: 25).

\section{Simpulan dan Saran}

\section{Simpulan}

Sertipikat hak atas tanah disebut sebagai bukti terkuat dalam membuktikan hubungan hukum dari suatu hak atas tanah, tetapi pada kenyataannya sertipikat hak atas tanah belum sepenuhnya mampu menjamin kepastian hukum tersebut oleh karena undang-undang masih membuka celah bagi subyek hukum 
lain untuk mempermasalahkannya baik secara personal maupun berkelompok (masyarakat) di lembaga peradilan.

\section{Saran}

Dalam rangka menjaminan kepastian hukum terhadap suatu hak atas tanah bagi pemegang haknya maka sertipikat hak atas tanah harus dapat diuji dalam tiga aspek yaitu terkait dengan; kepastian hukum atas objek, kepastian hukum atas status hak dan kepastian hukum atas subjek, sehingga Badan Pertanahan Nasional (BPN) sebagai stakeholder penerbit sertipikat hak atas tanah diharapkan agar lebih jeli, teliti dalam memastikan keakuratan data subjek, data objek dan status hak atas tanah yang akan diterbitkan sertipikatnya. 


\section{DAFTAR PUSTAKA}

\section{Buku:}

Adrian Sutedi. 2012. Sertipikat Hak Atas Tanah. Jakarta: Sinar Grafika.

Boedi Harsono. 2007. Hukum Agraria Indonesia, Himpunan Peraturan-peraturan Hukum Tanah. Jakarta: Djambatan.

Istanto, F.S. 2007. Penelitian Hukum. Yogyakarta: CV. Ganda.

Lubis, Muhammad Yamin dan Abdul Rahim Lubis. 2012 .Hukum Pendaftaran Tanah. Edisi Revisi. Bandung: Mandar Maju.

Marzuki, P.M. 2005. Penelitian Hukum. Jakarta: Kencana Prenada Media Group.

Muchtar Wahid. 2008. Memaknai Kepastian Hukum Hak Milik Atas Tanah; Suatu Analisis dengan Pendekatan Terpadu Secara Normatif dan Sosilogis. Jakarta: Penerbit Republika.

Samun Ismaya. 2013. Hukum Adminitrasi Pertanahan. Yogyakarta: Graha Ilmu.

Urip Santoso. 2010. Pendaftaran dan Peralihan Hak atas Tanah. Jakarta: Kencana Prenada Media Group.

\section{Jurnal/Artikel:}

Rahmat Ramadhani. 2012. "Benang Merah: Alas Hak dengan Sengketa Pertanahan". Artikel. Harian Rakyat Bengkulu. Kamis. 26 Juli.

Urip Santoso. 2015. "Perolehan Hak Atas Tanah yang Berasal dari Tanah Reklamasi Pantai”. Jurnal Mimbar Hukum. Volume 27. Nomor 2. Juli.

\section{Peraturan perundang-undangan:}

Republik Indonesia, Undang-undang Nomor 5 Tahun 1960 tentang Peraturan Dasar Pokok-pokok Agraria.

Republik Indonesia, Peraturan Pemerintah Nomor 24 Tahun 1997 tentang Pendaftaran Tanah.

Republik Indonesia, Peraturan Menteri Negara Agraria/Kepala Badan Pertanahan Nasional Nomor 3 Tahun 1997 tentang Ketentuan Pelaksana Peraturan Pemerintah Republik Indonesia Nomor 24 Tahun 1997 tentang Pendaftaran Tanah. 


\section{Internet:}

Iis Mardeli. "Kepastian Hukum”. https://iismardeli30aia.wordpress.com. Diakses tanggal 24 Mei 2017

Surabaya Pagi. "Kepastian Hukum”. http://www.surabayapagi.com. Diakses tanggal 30 April 2017. 


\section{BIODATA PENULIS}

$\begin{array}{ll}\text { Nama } & \text { : Rahmat Ramadhani, S.H., M.H } \\ \text { Pekerjaan } & \text { : Dosen Fakultas Hukum Universitas Muhammadiyah Sumatera } \\ & \text { Utara } \\ \text { Jabatan } & : \text { Asisten Ahli } \\ \text { Nomor HP } & : \text { 085361231979 } \\ \text { E-mail } & : \text { dhanilla1980@ gmail.com } \\ \text { Alamat Kantor } & : \text { Jl. Kapten Muchtar Basri No. 3, Medan }\end{array}$ 